Reprod. Nutr. Dévelop., 1986, 26 (2 A), 503-514.

\title{
Short-term (8-day) effects of a raw soybean diet on exocrine pancreatic secretion and plasma gastrointestinal hormone levels in the pig
}

\author{
T. CORRING, Anne-Marie GUeUgneaU, J. A. CHAYVIALLE (*)
}

with technical assistance of Georgette BRACHET, Christine BERNARD $\left(^{*}\right)$ and F. COINTEPAS

Laboratoire de Physiologie de la Nutrition,

I.N.R.A. 78350 Jouy-en-Josas France

(*) INSERM, Unité de Recherches de Physiopathologie

Hôpital E. Herriot, 69834 Lyon Cedex 2, France.

Summary. The aim of the present study was to investigate the short-term (8-day) effects of feeding a raw soybean diet on exocrine pancreatic secretion and the plasma levels of gastrointestinal hormones in pigs. After adaptation to a heated soybean diet, 6 pigs 136.5 $\pm 0.8 \mathrm{~kg}$ ) were fitted with permanent fistulae of the pancreatic duct, the duodenum and a carotid artery. After post-surgical recovery of 8 days, the animals were submitted to two experimental periods, a 4-day period during which they were fed the heated soybean diet and an 8-day period during which they received the raw soybean diet. Exocrine pancreatic secretion and plasma levels of secretin, cholecystokinin, VIP, PP, somatostatin and gastrin were monitored each day of the two experimental periods.

On the first day of raw soybean ingestion and till its end, the daily volume of pancreatic juice was higher than the mean volume measured during heated soybean ingestion. On the contrary, daily total protein output was unchanged. Specific activies of chymotrypsin, amylase and lipase were not modified by the raw soybean diet whereas, from the third day of the experimental period, that of trypsin was higher than the corresponding mean value determined during the first experimental period. Plasma levels of secretin and VIP were higher throughout raw soybean ingestion than the corresponding mean levels determined during the first experimental period. The plasma level of cholecystokinin increased only slightly and in the first days of the second experimental period only. The other gastrointestinal hormones studied were slightly (gastrin) or not (somatostatin, PP) affected by raw soybean feeding.

It is suggested that feedback control of exocrine pancreatic secretion in pigs was the mechanism involved in the increase of pancreatic juice observed when raw soybean was fed. This volume increase would result from secretin release into the blood.

\section{Introduction.}

The effects of feeding raw soybean meal on the pancreas of various animal species have been reported by numerous authors. According to the species, the pancreatic gland undergoes hypertrophy and/or hyperplasia and tissue enzyme activities are either enhanced or decreased. Based on data in the literature, Liener (1977) has hypothesized that pancreatic enlargment occurs only in species in which 
pancreatic weight exceeds $0.3 \%$ of body weight and not in species in which it is less. Thus, pancreatic response to raw soybean feeding would result from different control mechanisms specific to the animal species. In rats (Green and Lyman, 1972 ; Yanatori and Fujita, 1976 ; Wilson et al., 1978) and hamsters (Hasdai and Liener, 1983 ; Andren-Sandberg and Ihse, 1983), the feedback control of exocrine pancreatic secretion, as well as the release and effect of cholecystokinin, would explain pancreatic tissue hypertrophy. In pigs, which do not show pancreatic enlargement but decreased tissue enzyme activities (Yen, Jensen and Simon, 1977), the mechanism involved in the effect of raw soybean feeding on pancreatic secretion is unknown.

This research was undertaken to study the short-term effects of a raw soybean diet on pancreatic exocrine secretion and the plasma levels of some gastrointestinal hormones in fistulated pigs.

\section{Material and methods.}

Animals and diets. - Six growing, castrated, male Large-White pigs were successively fed a diet containing heated soybean $\left({ }^{*}\right)$ and one containing raw soybean $\left(^{*}\right)$ according to the experimental design. The diets (see composition in table 1) were isoproteic (16\% proteins) and isocaloric (3900 kcal/ $\mathrm{kg}$ ). The trypsin inhibitor content, determined according to Hamerstrand, Black and Glover (1981), was $1.41 \mathrm{mg} / \mathrm{g}$ in the heated soybean diet and $11.5 \mathrm{mg} / \mathrm{g}$ in the raw soy-

TABLE 1

Composition of the experimental diets.

\begin{tabular}{lcc}
\hline & \multicolumn{2}{c}{ Diets } \\
\cline { 2 - 3 } Item & Heated soybean & raw soybean \\
\hline Component, \% of fresh matter: & & \\
Heated soybean (1) & 26 & 26 \\
Raw soybean (1) & 31 & 31 \\
Barley (1) & & 38 \\
Cassava (1) & 1.5 & 1.5 \\
Tallow & 2.5 & 2.5 \\
Mineral mix (2) & 1.0 & 1.0 \\
Vitamin mix (3)
\end{tabular}

(1) Total nitrogenous matter \% dry matter : heated soybean : 54.5 ; raw soybean : 54.1 ; barley : 9.8 ; cassava : 3.1 .

(2) In p. cent of the diet : Calcium carbonate : 0.45 ; Magnesium Hydrate : 0.20 ; Potassium chloride : 0.40 ; Bicalcic phosphate: 1.0; Sodium chloride: 0.30 . Trace elements in $\mathrm{mg} / \mathrm{kg}$ diet : $\mathrm{CuSO}_{4}$, $5 \mathrm{H}_{2} \mathrm{O}: 36 ; \mathrm{ZnSO}_{4}, \mathrm{H}_{2} \mathrm{O}: 398 ; \mathrm{FeSO}_{4}, 7 \mathrm{H}_{2} \mathrm{O}: 452 ; \mathrm{MnSO}_{4}, \mathrm{H}_{2} \mathrm{O}: 144 ; \mathrm{MgOH}: 141$.

(3) $\mathrm{ln} \mathrm{mg} / \mathrm{kg}$ diet : vitamin $A(500.000 \mathrm{l} . \mathrm{U} / \mathrm{g}): 10 ;$ Vitamin $D_{3}(100.000$ I.U./g) : $10 ;$ Vitamin $E(250$ l.U./g): 22 ; Vitamin $\mathrm{K}: 4.4$; Vitamin $\mathrm{B}_{1}: 3$; Vitamin $\mathrm{B}_{2}: 6$; Vitamin $\mathrm{B}_{6}: 3$; Folic acid: 2 ; Paraminobenzonic acid: 20 ; Vitamin $B_{12}(500 \mathrm{mg} / \mathrm{kg}): 60$; Inositol : 200 ; Biotin (1\%): 0.3 ; Calcium pantothenate : 30 ; Choline $(50 \%): 3.000$; Niacine : 36 .

(*) Société Industrielle des Oléagineux, S.I.O. Arras (France). 
bean diet. Food was given daily at 9 a.m. and 4 p.m. in two meals of $800 \mathrm{~g}$ each diluted in water (W/v: 1/2).

Experimental design. - The pigs were adapted to the heated soybean diet for 8 days before surgery when the pancreatic duct, the duodenum and a carotid artery were permanently fistulated at a mean liveweight of $36.5 \pm 0.8 \mathrm{~kg}$. After surgery, they were put into individual metabolism-type cages and fed the heated soybean diet during the 8-day recovery period and the first 4-day experimental period. The raw soybean diet was given during the second experimental period ( 8 days). The duration of the recovery period was studied previously (Corring, Aumaitre and Rérat, 1972). It was shown that daily volume and daily total protein output stabilized from the 6th day after surgery and that any effect on pancreatic secretion could be determined over at least a 2 -week period.

Measurement of pancreatic secretion. - The pigs were fistulated according to Corring, Aumaitre and Rérat (1972). The catheters for pancreatic juice collection and return were connected to an apparatus which immediately reintroduced the secreted pancreatic juice into the duodenum and automatically gave a precise record of its volume at the same time that a sample of the secreted juice was continuously withdrawn for analysis (Juste, Corring and Le Coz, 1983).

Arterial blood sampling. - The catheter in a carotid artery was used to sample arterial blood at noon and at 4 p.m. on each day of the two experimental periods. These sampling times were chosen according to the level of pancreatic secretion which was stimulated by food intake (noon) and low at 4 p.m. Blood $(10 \mathrm{ml})$ was collected in ice-chilled tubes containing 10 units of heparin and 500 units of trasylol apronitin per $\mathrm{ml}$ of blood. Plasma aliquots were rapidly prepared after centrifugation $\left(1600 \mathrm{G}, 4{ }^{\circ} \mathrm{C} ; 15 \mathrm{~min}\right)$ and stored at $-80^{\circ} \mathrm{C}$ until assay of the regulatory peptides.

Analysis.

$1^{\circ}$ Pancreatic juice. - Using the automatic apparatus restituting the pancreatic juice, a daily sample was collected each day of the two experimental periods. This sample was absolutely representative of the total daily secretion and amounted to $4 \%$ of the latter (Juste, Corring et Le Coz, 1983). Total proteins and lipase, amylase, trypsin and chymotrypsin activities were determined in all samples.

Total proteins were determined according to Lowry et al. (1951). Lipase activity was measured by titrimetry at $\mathrm{pH} 9.0$ on a triolate substrate in the presence of bovine bile salts ( $6 \mathrm{mM}$ final concentration) and after lipase saturation by colipase prepared elsewhere from fresh pig pancreas (homogeneization and precipitation at $\mathrm{pH} \mathrm{2,} \mathrm{centrifugation} \mathrm{and} \mathrm{lyophilisation} \mathrm{of} \mathrm{the} \mathrm{supernatant).} \mathrm{Amylase} \mathrm{acti-}$ vity was determined according to the modified method of Metais and Bieth (1968) on biological samples containing high amylase activity (Corring and Saucier, 1972). We determined the number of amylase units contained in the pancreatic juice and which catalyze $1 \mathrm{mg}$ of soluble starch for $30 \mathrm{~min}$ at $37^{\circ} \mathrm{C}$. After proenzyme activation, chymotrypsin and trypsin activities were measured by titri- 
metry on ATEE and BAEE substrates, respectively (Reboud, Ben Abdeljlil and Desnuelle, 1962).

$2^{\circ}$ Hormone radioimmunoassays. - Immuno-reactive secretin, cholecystokinin, gastrin, somatostatin, vasoactive intestinal peptide (VIP) and pancreatic polypeptide (PP) were measured in the arterial plasma.

Gastrin, secretin, somatostatin and VIP were measured according to previously reported methods (Pelletier, Chayvialle and Minaire, 1978 ; Chayvialle et al., 1978). The PP assay was based on antiserum 26B (final $1 / 300000$ ) generated in a rabbit after three injections of synthetic bovine PP (Bachem) conjugated to bovine albumin through carbodiimide condensation. Bovine PP was labelled with 125 iodine (Amersham) using lactoperoxidase and purified by reverse-phase high performance liquid chromatography (RP-HPLC, Bondopak C18, Waters) in isocratic conditions (triethylamonium phosphate $\mathrm{pH} 3.5$ /acetonitrile, 68: 32). The within-assay and between-assay variations estimated in 30 samples were 6 and $9 \%$, respectively.

The cholecystokinin assay was developed with rabbit antiserum (67H) which equally recognized CCK 33, CCK 39 and 9 amino-acids or more sulfated carboxy terminal-end molecular forms. The reactivity of the $\mathrm{C}$-terminal octapeptide was $30 \%$, that of the non-sulfated peptide and of gastrin being less than $3 \%$. Carboxy terminal-end decapeptide (gift from $\operatorname{Pr} \mathrm{E}$. Wunsch) was used as a tracer and labelled with mono-iodinate Bolton and Hunter reagent. Purification was performed according to Fourmy et al. (1982). Plasma samples were checked ayainst a standard curve determined with charcoal absorbed plasma from each animal. Recovery of CCK 33 and CCK 8 ranged from 62 to $80 \%$. Within-assay and between-assay variations were 9 and $13.5 \%$, respectively.

Statistical analysis. - The data were analyzed by conventional least-squares analysis for a complete random design. Individual treatment mean comparisons were tested by multiple range techniques (Dagnélie, 1970).

\section{Results.}

Food intake was total when the pigs received the heated soybean diet. In the second experimental period of 8 days, when the raw soybean diet was offered, 4 pigs refused $0.987 \mathrm{~kg}, 1.121 \mathrm{~kg}, 1.351 \mathrm{~kg}$ and $1.681 \mathrm{~kg}$, respectively, of the $12.8 \mathrm{~kg}$ distributed. Refusals were observed from the 4 th day of the raw soybean period in one pig and from the 5th day in the others. In the whole post-surgical period (20 days), weight gain was $2.5 \pm 0.3 \mathrm{~kg}$.

Daily volume of pancreatic juice (tab/e 2). - The volume of pancreatic juice secreted per day significantly increased on the first day of the raw soybean period and was higher till the end of the experiment than the mean daily volume recorded during heated soybean ingestion. The highest increases were observed on day $1(+32 \%)$ and day $6(+30 \%)$ of the second experimental period. Examination of hourly volumes clearly indicated that pancreatic volume was higher at all times of the day during the raw soybean period than corresponding values recorded during the heated soybean period. 
ปั

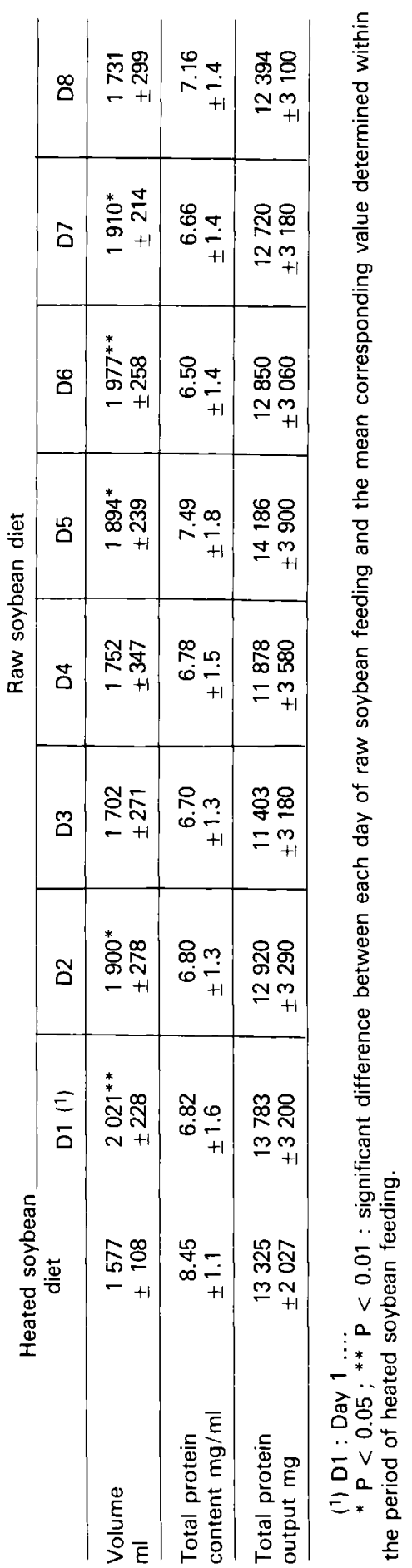

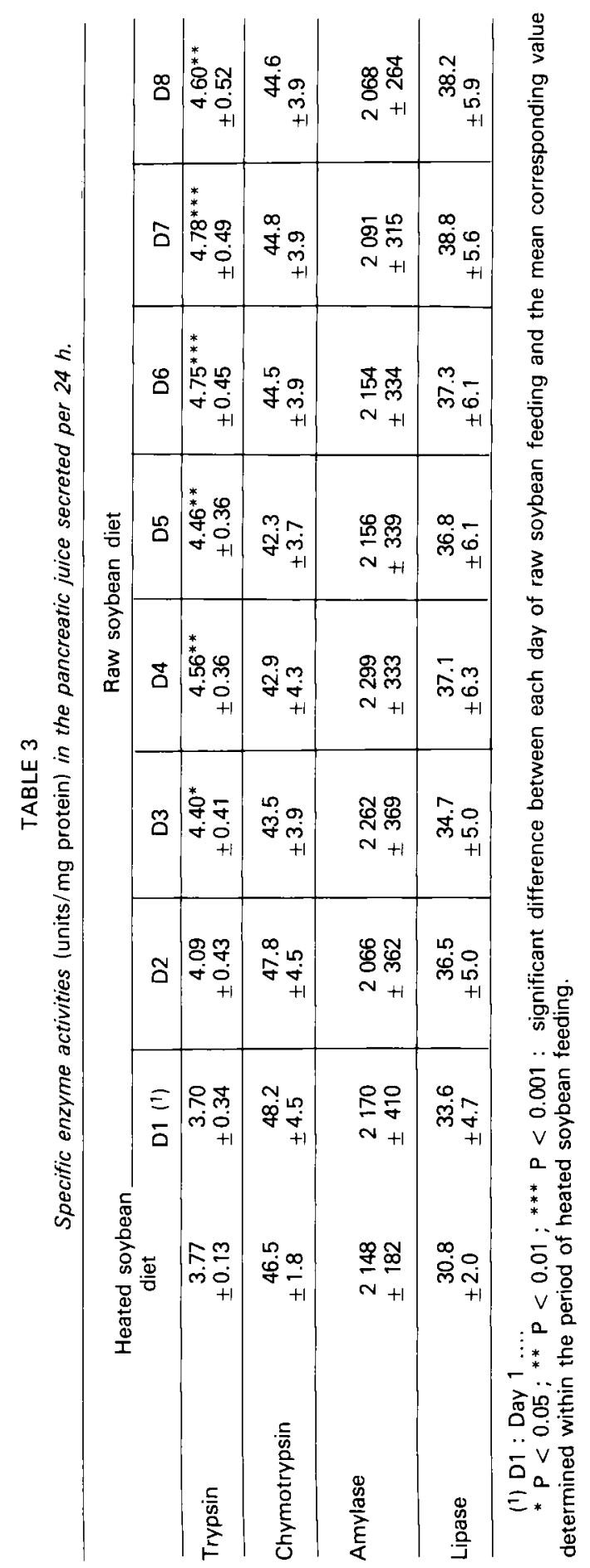


Total protein content of pancreatic juice (table 2). - The total protein content of the pancreatic juice secreted per 24 hours was not significantly affected by raw soybean feeding. This content tended to decrease in the second experimental period (on an average : $-19 \%$ ).

Daily protein output (table 2). - The daily total protein output in the pancreatic juice (volume $x$ content) was not significantly different on any day of the second experimental period than the corresponding mean value determined during heated soybean ingestion.

Specific enzyme activities (table 3). - Feeding the raw soybean diet did not significantly modify the specific activities of chymotrypsin, amylase or lipase. On the contrary, the specific activity of trypsin increased on day 3 and was higher till the end of the second experimental period than the corresponding mean value determined during the first experimental period (mean increase : $+21 \%$ ).

Plasma gastrointestinal hormone levels.

- Secretin (table 4). The plasma secretin level significantly rose at noon $(+79 \%)$ and at 4 p.m. $(+89 \%)$ on the first day of the raw soybean period. It was higher at noon during the first 3 days of this period (mean increase : $+78 \%$ ) and at 4 p.m. (mean overall increase : $+89 \%$ ) than the corresponding mean values determined in the first experimental period.

- VIP (table 4). The plasma VIP level significantly increased on day 1 and was higher throughout the second experimental period than the corresponding mean values determined during heated soybean ingestion. The mean increases during the raw soybean ingestion were $+136 \%$ at noon and $+86 \%$ at 4 p.m.

- CCK (table 4). The plasma CCK level was higher at noon when the pigs received the raw soybean diet than when they were fed the heated soybean diet. Thereafter the increase at noon was only significant during the first 4 days and the last day of the second experimental period (mean increase : + $65 \%$ ). At 4 p.m., the increase was not so high (mean : $+44 \%$ ) and was significant only during the first 3 days.

- Other peptides (table 5). Feeding the raw soybean diet did not affect the plasma levels of somatostatin and PP, whatever the time of blood collection. The plasma gastrin level rose at noon, but differences with the mean corresponding level determined during the first experimental period, were significant only on days 2,3 and 8 of the second experimental period.

\section{Discussion.}

This study shows that short-term (8-day) intake of a raw soybean diet did not lead to the hypersecretion of pancreatic juice enzymes in pigs, as reported by Schumann et al. (1983), or in rats submitted to intestinal perfusion of soybean trypsin inhibitor (Green and Lyman, 1972). In agreement with the results of Schumann et al., there was a pronounced effect on the volume of juice secreted per day and which increased. A similar effect was observed in one pig by thse and Lilja (1979) and in rats fed on raw soybean (Oates and Morgan, 1982). 


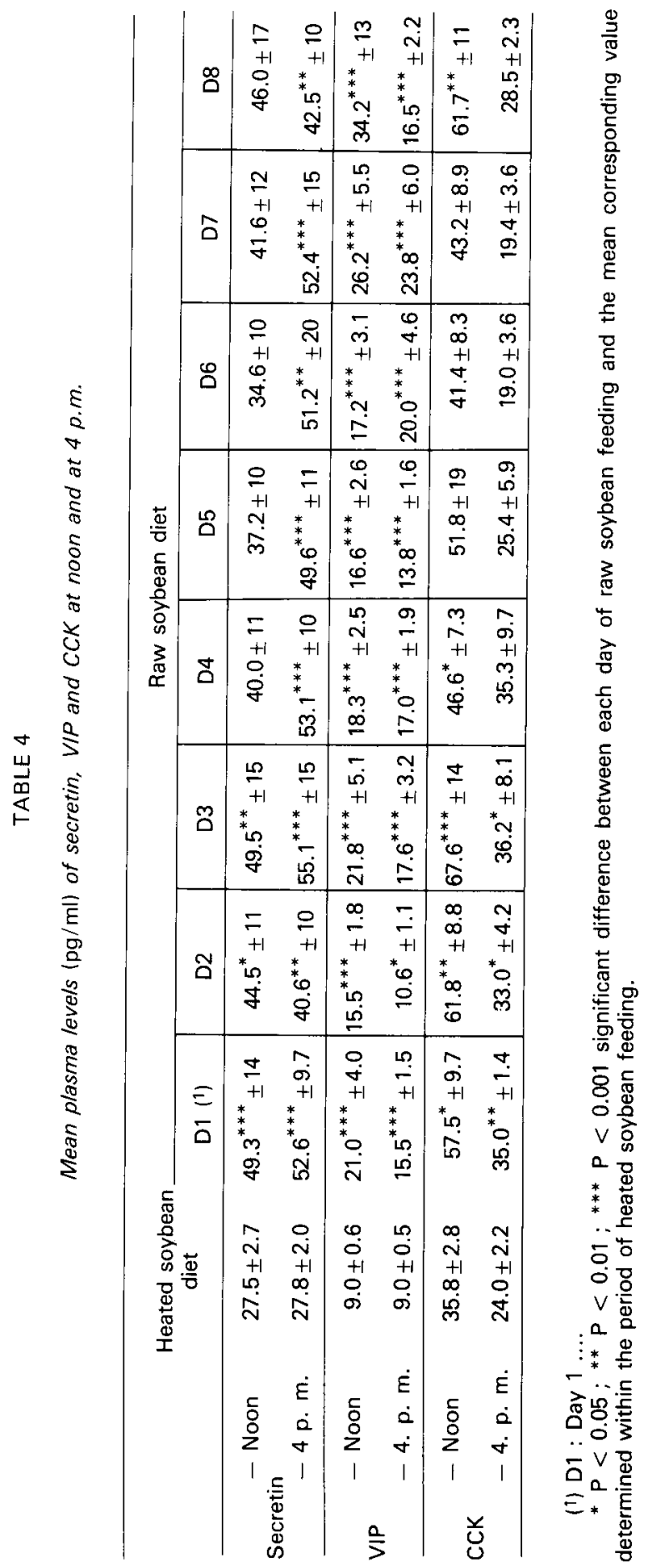




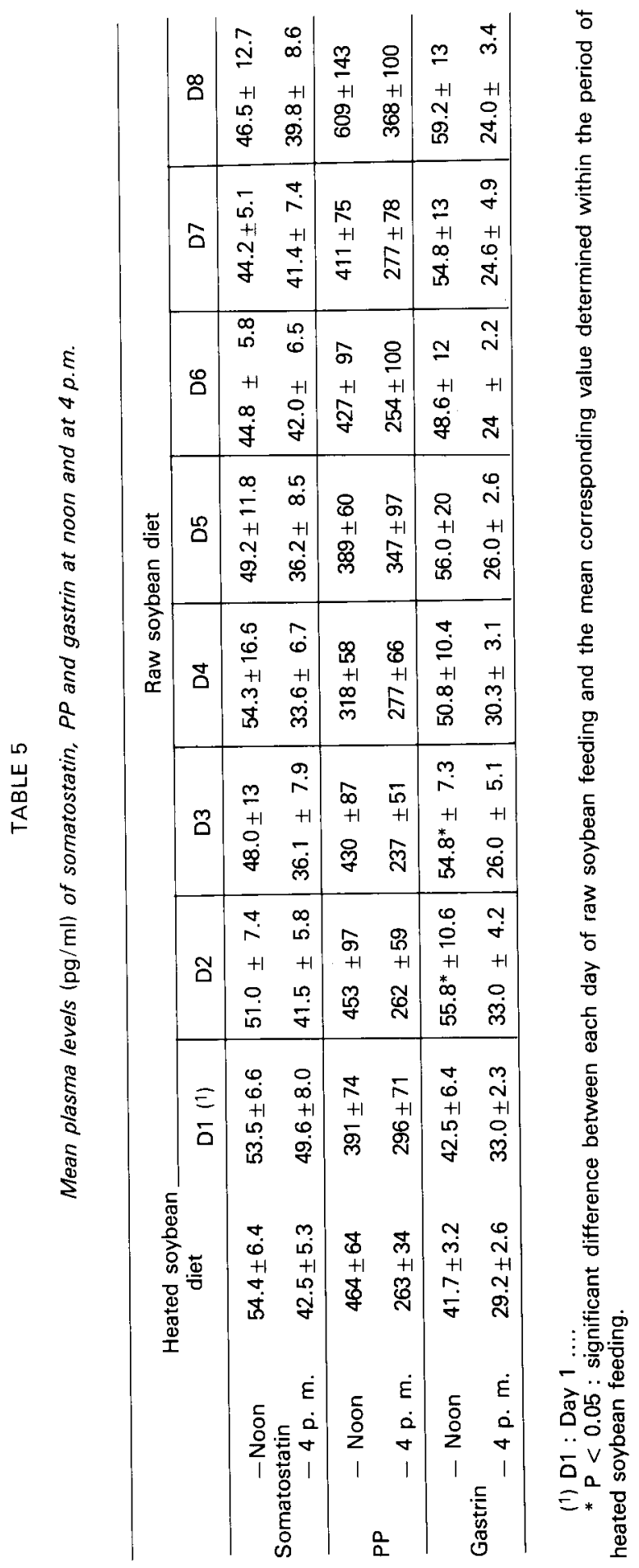


In our experiment, the protein content of the pancreatic juice decreased by about $19 \%$, even if it was not significant. Thus, total protein output was not modified by raw soybean feeding. On the contrary, in the study of Schumann et al. (1983), the protein content of the pancreatic juice did not change and total protein output increased.

In the present study, the specific activity of trypsin increased by $21 \%$ on the average, whilst that of the other enzymes studied did not change when the pigs were fed the raw soybean diet. Yen, Jensen and Simon (1977) have shown that the specific activities of trypsin and chymotrypsin in the pancreatic tissue were not modified in pigs fed with raw soybean for 2 weeks. These activities were nevertheless depressed at the end of a 6-week period of raw soybean feeding. Such a tissue depletion could result from an increased output of enzymes in the juice and it may be that in our experiment, trypsin activity was the first to increase during the response of the exocrine pancreas to raw soybean feeding.

The results of Schumann et al. (1983) are not in good agreement with this hypothesis since they report an increase in all the enzyme activities of the pancreatic juice of the pigs they studied. Their data must be reviewed cautiously because their study concerned only one 24-h hour period.

Feeding the raw soybean diet led to significant changes in some of the plasma levels of the gastrointestinal hormones studied. The levels of secretin and VIP, peptides regulating the volume of pancreatic juice (Jensen et al., 1978a, b), increased and were considerably higher than the corresponding values determined when the heated soybean diet was fed. The level of cholecystokinin also increased ; in its sulfated octapeptide form this product is a regulatory peptide of pancreatic enzyme secretion in pigs (Jensen et al., 1981). The results indicate that plasma hormone levels were affected by the time of sample collection. Because raw soybean did affect pancreatic volume in the same way, whatever the time of day, our results only show a daily relationship between plasma hormone levels and variations in pancreatic volume. It is known that meal intake leads to a release of CCK into the blood of pigs (Adrian and Bloom, 1981; Corring and Chayvialle, unpublished), whilst it does not affect secretin. Plasma secretin level is therefore high during the interdigestive periods, namely, during the night. In the present study the CCK level increased more at noon, i.e. after meal intake, than at 4 p.m., whereas secretin level was higher at 4 p.m. than at noon. Plasma VIP level increased more at noon than at 4 p.m. $(136 \%$ vs $86 \%)$; this might reflect the stimulatory effect of meal intake on this peptide release, as reported by Chayvialle et al. (1980). It is known that VIP is mainly a neurotransmitter (Larsson et al., 1978) and that in pigs it has less effect on pancreatic secretion than does secretin (Jensen et al., 1978b). According to Fahrenkrug (1979), local reflexes may initiate VIP-mediated increases in blood flow. The variations in plasma VIP level observed in our experiment may reflect the release of excess peptide from nerve endings due to the stimulatory effect of the raw soybean diet.

Somatostatin and pancreatic polypeptide which are known to inhibit exocrine pancreatic secretion in humans (Konturek et al., 1976) and in calves (Davicco, Lefaivre and Barlet, 1979), and gastrin, a regulatory peptide of gastric secretion (Fujita et al., 1980), was not or only slightly affected when a raw soybean diet was given. 
The results obtained in the present study show that the pattern of pancreatic secretion volume and those of plasma secretin and VIP levels were similar when raw soybean was substituted for heated soybean in diets ingested by pigs. We suggest that the release of VIP, and mainly of secretin, could explain the increase in the volume of pancreatic secretion, although we could not determine the respective parts of the two peptides in the stimulation of pancreatic secretion without carying out immuno-neutralization experiments. It was shown that the plasma CCK level increased at the beginning of raw soybean ingestion, whereas the content and amount of the total proteins secreted in the pancreatic juice did not change. These apparently contradictory results cannot be explained. We can only suggest that either the rise in blood CCK level did not stimulate pancreatic enzyme secretion or that CCK is not a potent regulatory peptide of pancreatic secretion in pigs.

In a previous study (Corring et al., 1985), it was shown that removing the pancreatic juice from the duodenal lumen in pigs caused an increase in exocrine pancreatic secretion which was mainly due to an increase in its volume. At the same time, the level of plasma secretin was enhanced. Similar mechanisms would be involved when soybean trypsin inhibitors are ingested by pigs and when the pancreatic juice, i.e. proteolytic enzymes, is removed from the intestinal lumen. Some authors have postulated that feedback control of pancreatic secretion would be involved in the response of the exocrine pancreas when raw soybean or its trypsin inhibitor is fed (Green and Lyman, 1972 ; Schumann et al., 1983). Pancreatic hypersecretion in rats would be due to CCK release into the blood (Yanatori and Fujita, 1976 ; Brand and Morgan, 1981). If feedback control of pancreatic secretion is implicated in the response of the pig pancreas to raw soybean feeding, it involves a release of secretin into the blood.

Reçu en juillet 1985. Accepté en décembre 1985.

Résumé. Effets à court-terme ( 8 jours) de la consommation d'un régime à base de soja cru sur la sécrétion pancréatique exocrine et les niveaux plasmatiques d'hormones gastrointestinales chez le porc.

Le but du travail rapporté était d'étudier chez le porc fistulé les effets de la consommation à court-terme du tourteau de soja cru sur la sécrétion pancréatique exocrine et le niveau plasmatique de quelques hormones gastro-intestinales. Après adaptation à un régime contenant du tourteau de soja cuit (régime soja cuit), 6 porcs $(36,5 \pm 0,8 \mathrm{~kg})$ ont été munis de fistules permanentes du canal pancréatique, du duodénum et d'une artère carotide. Après une période de réhabilitation post-opératoire de 8 jours, ils ont subi deux périodes expérimentales, I'une de 4 jours au cours de laquelle ils recevaient le régime soja cuit, et l'autre, immédiatement consécutive, de 8 jours au cours de laquelle ils ont reçu un régime à base de tourteau de soja cru (régime soja cru). La sécrétion pancréatique par $24 \mathrm{~h}$ et les taux plasmatiques de la sécrétine, de la cholécystokinine, du VIP, du PP, de la gastrine et de la somatostatine ont été déterminés chaque jour des deux périodes expérimentales.

Dès le $1^{\text {er }}$ jour de la période de consommation du régime soja cru et jusqu'en fin d'expérimentation, le volume de suc pancréatique écoulé a été supérieur au volume moyen déterminé pendant la période de consommation du régime soja cuit. En revanche, la quantité de protéines totales pancréatiques sécrétées par $24 \mathrm{~h}$ n'a pas été modifiée. Les activités spécifiques enzymatiques de la chymotrypsine, de l'amylase et de la lipase n'ont pas été affectées par la consommation du régime soja cru tandis que celle de la trypsine a été supé- 
rieure, à partir du $3^{e}$ jour de la période de consommation du régime soja cru, à l'activité enzymatique moyenne correspondante mesurée lors de la période d'ingestion du régime soja cuit. En ce qui concerne les hormones gastro-intestinales, les niveaux plasmatiques de la sécrétine et du VIP ont été supérieurs, chaque jour de la seconde période expérimentale, aux niveaux moyens correspondants déterminés au cours de la première période expérimentale. Le niveau de la cholécystokinine a également subi une augmentation, mais plus faible et seulement au cours des premiers jours de la seconde période expérimentale. Les autres hormones étudiées ont été peu (gastrine) ou pas affectées (somatostatine, PP) par la consommation du régime soja cru.

Il est suggéré que chez le porc, le mécanisme de régulation de la sécrétion pancréatique par rétroaction négative est à l'origine de l'augmentation du volume de suc pancréatique observée après consommation du régime soja cru. Cette augmentation serait principalement due à la libération de sécrétine circulante.

\section{References}

ADRIAN T. E., BLOOM S. R., 1981. Nutrition in health and disease and international development, 873-882. Symp. XII Int. Congr. Nutr., A. E. HARPER and G. K. DAVIS Eds.

ADREN-SANDBERG A., IHSE I., 1983. Regulatory effects on the pancreas of intraduodenal pan creatic juice and trypsin in the Syrian golden hamster. Scand. J. Gastroenterol., 18, 697-706.

BRAND S. J., MORGAN R. G. H., 1981. The release of rat intestinal cholecystokinin after oral trypsin inhibitor measured by bio-assay. J. Physiol., 319, 325-343.

CHAYVIALLE J. A., DESCOS F., BERNARD C., MARTIN A., BARBE C., PARTENSKY C., 1978. Somatostatin in mucosa of stomach and duodenum in gastroduodenal disease. Gastroenterology, 75, 13-19.

CHAYVIALLE J. A., MIYATA M., RAYFORD P. L., THOMPSON J. C., 1980. Effects of test meal, intragastric nutrients, and intraduodenal bile on plasma concentrations of immuno-reactive somatostatin and vasoactive intestinal peptide in dogs. Gastroenterology, 79, 844-852.

CORRING T., AUMAITRE A., RÉRAT A., 1972. Fistulation permanente du pancréas exocrine chez le porc. Application : réponse de la sécrétion pancréatique au repas. Ann. Biol. anim. Bioch. Biophys., 12, 109-124.

CORRING T., CHAYVIALLE J. A., SIMOES-NUNES C., ABELLO J., 1985. Régulation de la sécrétion pancréatique par rétroaction négative et hormones gastro-intestinales plasmatiques chez le porc. Reprod. Nutr. Dévelop., 25, 439-450.

CORRING T., SAUCIER R., 1972. Sécrétion pancréatique sur porc fistulé. Adaptation à la teneur en protéines du régime. Ann. Biol. anim. Bioch. Biophys., 12, 233-241.

DAGNÉLIE P., 1970. Les comparaisons multiples de moyennes, 241-261. In DUCULOT J., Théorie et méthodes statistiques. Applications agronomiques, vol. II. Presses Agronomiques, Gembloux, Belgique.

DAVICCO M. J., LEFAIVRE J., BARLET J. P., 1979. The influence of bovine pancreatic polypeptide on pancreatic exocrine secretion in young calves. Ann. Biol. anim. Bioch. Biophys., 19, 843-848.

FAHRENKRUG J., 1979. Vasoactive intestinal polypeptide : measurement, distribution and putative neurotransmitter function. Digestion, 19, 149-169.

FOURMY D., PRADAYROL L., ANTONIOTTI H., ESTEVE J. P., RIBET A., 1982. Purification of radio-iodinated cholecystokinin peptides by reverse phase HPLC. J. Liquid Chromat., 5, 757 766.

FUJITA S., KOKUE E. I., KUREBAYASHI Y., HAYAMA T., 1980. Secretory kinetics of electrolytes in porcine gastric juice from Heidenhain pouch. Jpn. J. vet. Sci., 42, 401-406.

GREEN G. M., LYMAN R. L., 1972. Feed-back regulation of pancreatic enzyme secretion as a mechanism for trypsin inhibitor-induced hypersecretion in rats. Proc. Soc. exp. Biol. Med., 140, 6-12.

HAMERSTRAND G. E., BLACK L. T., GLOVER J. D., 1981. Trypsin inhibitors in soy products : modification of the standard analytical procedure. Cereal. Chem., 58, 42-45.

HASDAI A., LIENER J. E., 1983. Growth, digestibility and enzymatic activities in the pancreas and intestines of hamsters fed raw and heated soy flour. J. Nutr., 113, 662-668. 
IHSE I., LILJA P., 1979. Effects of intestinal amylase and trypsin on pancreatic secretion in the pig. Scand. J. Gastroenterol., 14, 1009-1013.

JENSEN S. L., FAHRENKRUG J., HOLST J. J., KUHL C., NIELSEN O. V., SCHAFFALITZKY DE MUCKADELL O. B., 1978a. Secretory effects of secretin on isolated perfused porcine pancreas. Am. J. Physiol., 235, E381-E386.

JENSEN S. L., FAHRENKRUG J., HOLST J. J., NIELSEN O. V., SCHAFFALITZKY DE MUCKADELL O. B., 1978b. Secretory effects of VIP on isolated perfused porcine pancreas. Am. J. Physiol., 235, E387-E391.

JENSEN S. L., HOLST J. J., NIELSEN O. V., REHFELD J. F., 1981. Effect of sulfatation of CCK-8 on its stimulation of the endocrine and exocrine secretion from the isolated perfused porcine pancreas. Digestion, 22, 305-309.

JUSTE C., CORRING T., LE COZ Y., 1983. Bile restitution procedures for studying bile secretion in the fistulated pig. Lab. Anim. Sci, 33, 199-202.

KONTUREK S. J., TASLER J., OBTULOWICZ W., COY D. H., SCHALLY A. V., 1976. Effect of growth hormone-release inhibiting hormone on hormone stimulating exocrine pancreatic secretion. J. clin. Invest., 58, 1-6.

LARSSON L. I., FAHRENKRUG J., HOLST J. J., SCHAFFALITZKY DE MUCKADELL O. B., 1978. Innervation of the pancreas by vasoactive intestinal peptide (VIP) immunoreactive nerves. Life Sci, 22, 773-780.

LIENER I. E., 1977. Toxicological considerations in the utilization of new protein foods, 129-138. In ADLER-NISSEN J., Biochemical aspects of the new protein foods, Fed. Eur. Biochem. Soc., Copenhagen, Danemark.

LOWRY O. H., ROSEBROUGH N. J., FARRAND A. L., RANDALL R. J., 1951. Protein measurement with the Folin-phenol reagent. J. biol. Chem., 193, 265-275.

METAIS P., BIETH J., 1968. Determination de l' $\alpha$-amylase par une microtechnique. Ann. Biol. clin., 26, 133-142.

OATES P. S., MORGAN R. G. H., 1982. Pancreatic response to bolus injection of cholec) stokinin-pancreozymin in anaesthetized and conscious rats fed raw soyaflour. Aust. J. biol. Sci, 35, 505-515.

PELLETIER M. J., CHAYVIALLE J. A., MINAIRE Y., 1978. Uneven and transient secretin relase after a liquid test meal. Gastroenterology, 75, 1124-1132.

REBOUd J. P., BEN ABDELJLIL A., DESNUELLE P., 1962. Variations de la teneur en enzymes du pancréas de rat en fonction de la composition des régimes. Biochim. biophys. Acta, 58, 326-337.

SCHUMANN B., SOUFFRANT W. B., MATKOWITZ R., GEBHARDT G., 1983. Untersuchungen zur endogenen N-sekretion im Pankreassekret beim Schwein. Wiss. Z. Karl-Marx-Univ. Leipzig, Math. Naturwiss. R., 32, 570-575.

WILSON P. A., MELMED R. N., HAMPE M. M. V., HOLT S. J., 1978. Immunocytochemical study of the interaction of soybean trypsin inhibitor with rat intestinal mucosa. Gut, 19. 260-266.

YANATORI Y., FUJITA T., 1976. Hypertrophy and hyperplasia in the endocrine and exocrine pancreas of rats fed soybean trypsin inhibitor or repeatedely injected with pancreozymin. Arch. histol, jpn., 33, 67-68.

YEN J. T., JENSEN A. H., SIMON J., 1977. Effect of dietary raw soybean and soybean trypsin inhibitor on trypsin and chymotrypsin activities in the pancreas and in small intestinal juice of growing swine, J. Nutr., 107, 156-165. 